INTERNATIONAL FOOD

POLICY RESEARCH INSTITUTE

sustainable solutions for ending hunger and poverty

Supported by the CGIAR

IFPRI Discussion Paper 00840

December 2008

\title{
The Impact of Agricultural Extension and Roads on Poverty and Consumption Growth in Fifteen Ethiopian Villages
}

\author{
Stefan Dercon \\ Daniel O. Gilligan \\ John Hoddinott \\ Tassew Woldehanna
}

Food Consumption and Nutrition Division 


\section{INTERNATIONAL FOOD POLICY RESEARCH INSTITUTE}

The International Food Policy Research Institute (IFPRI) was established in 1975. IFPRI is one of 15 agricultural research centers that receive principal funding from governments, private foundations, and international and regional organizations, most of which are members of the Consultative Group on International Agricultural Research (CGIAR).

\section{FINANCIAL CONTRIBUTORS AND PARTNERS}

IFPRI's research, capacity strengthening, and communications work is made possible by its financial contributors and partners. IFPRI receives its principal funding from governments, private foundations, and international and regional organizations, most of which are members of the Consultative Group on International Agricultural Research (CGIAR). IFPRI gratefully acknowledges the generous unrestricted funding from Australia, Canada, China, Finland, France, Germany, India, Ireland, Italy, Japan, Netherlands, Norway, South Africa, Sweden, Switzerland, United Kingdom, United States, and World Bank.

\section{AUTHORS}

\section{Stefan Dercon, University of Oxford}

Department of Economics

Stefan.Dercon@economics.oxford.ac.uk

\section{Daniel O. Gilligan, International Food Policy Research Institute}

Research Fellow, Food Consumption and Nutrition Division

D.Gilligan@cgiar.org

\section{John Hoddinott, International Food Policy Research Institute}

Senior Research Fellow and Deputy Director, Food Consumption and Nutrition Division J.Hoddinott@cgiar.org

\section{Tassew Woldehanna, Addis Ababa University}

Department of Economics

wtassew@econ.aau.edu.et

\footnotetext{
Notices

${ }^{1}$ Effective January 2007, the Discussion Paper series within each division and the Director General's Office of IFPRI were merged into one IFPRI-wide Discussion Paper series. The new series begins with number 00689, reflecting the prior publication of 688 discussion papers within the dispersed series. The earlier series are available on IFPRI's website at www.ifpri.org/pubs/otherpubs.htm\#dp.

${ }^{2}$ IFPRI Discussion Papers contain preliminary material and research results. They have not been subject to formal external reviews managed by IFPRI's Publications Review Committee but have been reviewed by at least one internal and/or external reviewer. They are circulated in order to stimulate discussion and critical comment.
}

Copyright 2008 International Food Policy Research Institute. All rights reserved. Sections of this material may be reproduced for personal and not-for-profit use without the express written permission of but with acknowledgment to IFPRI. To reproduce the material contained herein for profit or commercial use requires express written permission. To obtain permission, contact the Communications Division at ifpri-copyright@cgiar.org 
Contents

Acknowledgments $\quad$ V

Abstract vi vi

1. Introduction 1

2. Data and Setting 3

3. Descriptives

4. Model and Results $\quad 7$

5. Conclusions 15

References 


\section{List of Figures}

1. Characteristics of the sample sites 4

2. The distribution of households in the Ethiopian Rural Household Survey, by agroecological zone 6

3. Determinants of consumption growth and poverty status: Basic results 9

4. Selected robustness checks on basic results 11

5. Impact of extension and all-weather roads on poverty by initial household characteristics 13

6. Impact of extension and all-weather roads on consumption growth by initial household characteristics 


\section{ACKNOWLEDGMENTS}

We thank the following organizations for funding the survey work on which this paper is based: Swedish International Development Cooperation Agency SIDA, United States Agency for International Development (USAID) and the World Food Program. Analysis was supported by funding received from USAID under BASIS grant LAG-4213-A-00-6016-00 and from the International Food Policy Research Institute's (IFPRI's) Ethiopian Strategy Support Program (ESSP). We have benefited from superb research assistance from Yisehac Yohannes and comments from seminar participants at Addis Ababa University, the Ethiopian Development Research Institute, the 2006 ESSP Policy Conference, IFPRI, three anonymous referees, and an AJAE editor. Errors are ours. 


\begin{abstract}
This paper investigates whether public investments that led to improvements in road quality and increased access to agricultural extension services led to faster consumption growth and lower rates of poverty in rural Ethiopia. Estimating an instrumental variables model using Generalized Methods of Moments and controlling for household fixed effects, we find evidence of positive impacts with meaningful magnitudes. Receiving at least one extension visit reduces headcount poverty by 9.8 percentage points and increases consumption growth by 7.1 percent. Access to all-weather roads reduces poverty by 6.9 percentage points and increases consumption growth by 16.3 percent. These results are robust to changes in model specification and estimation methods.
\end{abstract}

Keywords: public investment, roads, agricultural extension, income growth, poverty, Ethiopia 


\section{INTRODUCTION}

In many African countries, improving growth rates in agriculture is seen as critical for sustained poverty reduction. Such a view stems from the fact that while Africa is urbanizing, the vast majority of people still live in rural areas and derive livelihoods from agricultural activities. Nowhere is this truer than in Ethiopia, where agriculture accounts for 85 percent of employment nationally and 96 percent of employment in rural areas (World Bank 2005).

Public investments can play several roles in creating the enabling environment necessary to stimulate agricultural growth. One of these roles is through facilitating technology transfer. For example, by providing agricultural extension services, governments can inform farmers of new agricultural technologies, advise them on best farming practices, and assist them in dealing with adverse shocks such as insect infestations or plant diseases. A second role is the provision of infrastructure, most notably, improved roads. Better roads can reduce transaction costs associated with agricultural activities and in so doing have the potential to reduce the costs of acquiring inputs, to increase output prices, to reduce the impact of shocks, and to permit entry into new and more profitable activities. Governments frequently are involved in other dimensions of agricultural activities, and there is an a priori strong case for governments to undertake these investments given the public goods nature of roads and technology transfer.

Assessing the impact of these investments on welfare indicators such as poverty and consumption is not straightforward. In the case of agricultural extension, the allocation of extension efforts is not necessarily random across or within localities. Suppose governments decide to concentrate extension resources in areas that have high agricultural potential. If this purposive program placement is not taken into account, estimates of impact will be biased upwards (Birkhaeuser, Evenson, and Feder 1991; (Rosenzweig and Wolpin 1986). Concerns regarding such placement effects resonate in the Ethiopian context. Efforts by the government extension service to encourage farmers to adopt a fertilizer-improved seed-credit package in the 1990s were seen as leading to improvements in yields in some parts of the country. However, because these efforts were concentrated in areas with higher agricultural potential, placement effects may account for these improvements (World Bank 2005). The second bias is a form of selection bias. If better skilled farmers are more likely to seek out extension services, or if extension agents prefer to seek out such individuals, an analysis that does not take this farm-level characteristic into account would yield biased estimates of the impact of extension.

Uncovering the impact of investments in rural roads is also challenging. ${ }^{1}$ Like extension, road investments are often targeted, making it difficult to isolate causal impacts from placement effects. Other issues concern accurately capturing the impacts on a diffuse beneficiary group and accounting for substantial differences in road quality. One approach has been to relate country- or regional-level public expenditure data to changes in agricultural productivity (see Fan, Hazell, and Thorat 2000; Fan, Zhang, and Zhang 2002). An advantage of this approach is that it can form the basis of benefit-cost ratios and thus allow researchers to compare investments in infrastructure with other forms of public spending. However, these approaches do not tell us what component of infrastructure spending generates these benefits. They do not inform discussions as to whether it is the quantity of infrastructure that matters or its quality; nor, in the absence of distributional data, do most of these studies show the impact of these investments on poverty (Fan, Zhang, and Zhang 2002 being an exception). By contrast, household-level studies, such as Jalan and Ravallion (2002) and Jacoby (2000) can uncover the impact of infrastructure on poverty at the household level and, depending on the data available, take into account differences in infrastructural quality.

This paper explores the impact of agricultural extension and rural roads on consumption growth and poverty in Ethiopia from 1994 to 2004. With the dramatic decline in budgetary support for extension services in many developing countries over the past 20 years, this is an important and underresearched

\footnotetext{
${ }^{1}$ Fan and Chan-Kang (2005) provide a recent review of the literature on the links between infrastructure development, agricultural growth, and poverty.
} 
topic. Ethiopia is of particular interest in part because the government rejected this trend, substantially increasing expenditure on agricultural extension starting in 1997 as part of its Agricultural Development Led Industrialization (ADLI) strategy. However, there has been little careful analysis of the impact of this renewed investment in extension on consumption (for an exception, see Mogues, Ayele, and Paulos 2007) or on poverty. More generally, in three comprehensive reviews examining the impact of access to agricultural extension, including two that appear in the Handbooks of Agricultural Economics (Birkhaeuser, Evenson, and Feder 1991; Evenson 2001; Anderson and Feder 2007), there is no evidence of the direct impact of extension on poverty in a developing country context, nor are we aware of other studies that provide such evidence. For comparison with the results on extension, we also explore the impact of improvements in road quality on these welfare outcomes in Ethiopia. The impact of roads has been explored in this setting by Dercon (2004, 2006), but this paper updates and expands those results by making use of new data that were not used in the earlier Dercon papers and by examining the impact of roads on poverty as well as consumption growth. ${ }^{2}$

The paper begins by describing the longitudinal household survey data and presenting descriptive statistics outlining trends in consumption and poverty as well as changes in access to these public investments. We then sketch out a growth model that is used to inform our estimation strategy. To account for endogeneity concerns that arise, we use a Generalized Methods of Moments IV estimator, which has the advantage of being more efficient than a straightforward IV estimator. We also account for household fixed effects. This eliminates biases brought about by correlations between fixed household and locality characteristics and the placement of extension services and roads. It has the added advantage of eliminating attrition biases due to fixed household characteristics while controlling for the effect of spatial correlation across households. Using this estimator, we find that receiving at least one extension visit reduces headcount poverty by 9.8 percentage points and increases consumption growth by 7.1 percent. Access to all-weather roads reduces poverty by 6.9 percentage points and increases consumption growth by 16.3 percent. These results are robust to changes in model specification and estimation methods.

\footnotetext{
${ }^{2}$ Dercon (2004) uses data from only six of the ERHS villages for the period 1989-1997. Dercon (2006) uses data from only six villages for the period 1989-1995. By contrast, in this paper we use data from all 15 villages and use a longer (and more recent) time frame for our analysis: survey data from 1994, 1995, 1997, 1999, and 2004.
} 


\section{DATA AND SETTING}

Ethiopia is a federal country divided into 11 regions. Each region is subdivided into zones, and the zones into woredas, which are roughly equivalent to a county in the United States or UK. Woredas, in turn, are divided into peasant associations (PAs), or kebeles, an administrative unit consisting of a number of villages. PAs were set up in the aftermath of the 1974 revolution. Our data are taken from the Ethiopia Rural Household Survey (ERHS), a unique longitudinal household data set covering households in 15 areas of rural Ethiopia. Data collection started in 1989, when a survey team visited six PAs in central and southern Ethiopia. The survey was expanded in 1994 to encompass 15 PAs across the country, yielding a sample of 1,477 households. As part of the survey redesign and extension that took place in 1994, the sample was rerandomized by including an exact proportion of newly formed or arrived households in the sample, as well as by replacing households lost to follow-up with others considered broadly similar in terms of demographics and wealth by village elders and officials. The nine additional PAs were selected to better account for the diversity in the farming systems found in Ethiopia. Specifically, with these additional locations, the population shares within the sample were, as of 1994, broadly consistent with the population shares in the three main sedentary farming systems: the plow-based cereals farming systems of the Northern and Central Highlands, the mixed plow/hoe cereals farming systems, and the farming systems based around enset (a root crop also called false banana) that is grown in southern parts of the country. Table 1 provides some basic characteristics of these localities.

Sample sizes in each village were chosen so as to approximate a self-weighting sample when considered in terms of the farming system: each person (approximately) represents the same number of persons found in the main farming systems as of $1994 .{ }^{3}$ However, results should not be regarded as nationally representative. The sample does not include pastoral households or urban areas. ${ }^{4}$ Also, the practical aspects associated with running a longitudinal household survey when the sampled localities are as much as $1000 \mathrm{~km}$ apart in a country where top speeds on the best roads rarely exceed $50 \mathrm{~km} / \mathrm{hour}$ constrained sampling to only 15 communities in a country of thousands of villages. Extrapolation of these results should be done with care.

Following the first survey round on the 15-village sample in 1994, the same households were interviewed again in late 1994. They were again interviewed in 1995, 1997, 1999, and 2004. Households that attrited were not replaced. These surveys were conducted, either individually or collectively, by the Economics Department at Addis Ababa University, the Centre for the Study of African Economies, University of Oxford, or the International Food Policy Research Institute. Sample attrition between 1994 and 2004 is low in part because of this institutional continuity, with a loss of only 12.4 percent (or 1.3 percent per year) of the sample over this 10 -year period. ${ }^{5}$ This continuity also helped ensure that questions asked in each round were identical, or very similar, to those asked in previous rounds and that the data were processed in comparable ways.

\footnotetext{
${ }^{3}$ Sampling in the PAs newly included in 1994 was based on a list of all households constructed with the help of the local PA officials. The sample was stratified within each village to ensure that a representative number of landless households were also included. Similarly, an exact proportion of female-headed households were included via stratification. The PA was responsible for the implementation of land reform following 1974 and held wide-ranging powers as a local authority. All land is owned by the government. To obtain land, households have to register with the PA, and thus, lists are maintained of the households who have been allocated land. These household lists were a good source of information for the construction of a sampling frame.

${ }^{4}$ Pastoral areas were excluded, in part, because of the practical difficulties in finding and resurveying such highly mobile households over long periods of time.

${ }^{5}$ We examined whether this sample attrition is nonrandom. Over the period 1994-2004, $t$ tests of mean values for attriters and nonattriters showed no statistically significant differences in terms of initial levels of characteristics of the head (age, sex), assets (fertile land, all land holdings, cattle), or consumption. However, attriting households were, at baseline, smaller than nonattriting households. Between 1999 and 2004, there are some significant differences by village, with one village, Shumsha, having a higher attrition rate than others in the sample. Our survey supervisors recorded the reason why a household could not be traced. Using these data, we examined attrition in Shumsha on a case-by-case basis but could not find any dominant reason why households attrited. This result is also obtained when we estimate a probit model where the likelihood of attrition is the dependent variables.
} 
Table 1. Characteristics of the sample sites

\begin{tabular}{|c|c|c|c|c|c|}
\hline Survey Site & Location & Description & $\begin{array}{l}\text { Main } \\
\text { Crops }\end{array}$ & $\begin{array}{c}\text { Perennial } \\
\text { Crops }\end{array}$ & $\begin{array}{c}\text { Mean } \\
\text { Rainfall mm } \\
\end{array}$ \\
\hline Haresaw & Tigray & Poor and vulnerable area. & Cereals & no & 558 \\
\hline Geblen & Tigray & $\begin{array}{l}\text { Poor and vulnerable area; used to be quite } \\
\text { wealthy. }\end{array}$ & Cereals & no & 504 \\
\hline Dinki & N. Shoa & $\begin{array}{l}\text { Badly affected by 1984/85 famine; not easily } \\
\text { accessible even though near Debre Berhan. }\end{array}$ & Millet, teff & no & 1,664 \\
\hline $\begin{array}{l}\text { Debre } \\
\text { Berhan }\end{array}$ & N. Shoa & Highland site. Near town. & Teff, barley, beans & no & 919 \\
\hline Yetemen & Gojjam & $\begin{array}{l}\text { Near Bichena. Ox-plow cereal farming system } \\
\text { of highlands. }\end{array}$ & Teff, wheat, beans & no & 1,241 \\
\hline Shumsha & S.Wollo & $\begin{array}{l}\text { Poor area in neighborhood of airport near } \\
\text { Lalibela. }\end{array}$ & Cereals & no & 654 \\
\hline $\begin{array}{l}\text { Sirbana } \\
\text { Godeti }\end{array}$ & Shoa & $\begin{array}{l}\text { Near Debre Zeit. Rich area. Much targeted by } \\
\text { agricultural policy. Cereal, ox-plow system. }\end{array}$ & Teff & no & 672 \\
\hline Adele Keke & Hararghe & Highland site. Drought in 1985/86. & $\begin{array}{l}\text { Millet, maize, } \\
\text { coffee, chat }\end{array}$ & $\begin{array}{l}\text { yes, no } \\
\text { food }\end{array}$ & 748 \\
\hline Korodegaga & Arssi & $\begin{array}{l}\text { Poor cropping area in neighborhood of rich } \\
\text { valley. }\end{array}$ & Cereals & no & 874 \\
\hline $\begin{array}{l}\text { Turfe } \\
\text { Kechemane }\end{array}$ & S.Shoa & $\begin{array}{l}\text { Near Shashemene. Ox-plow, rich cereal area. } \\
\text { Highlands. }\end{array}$ & $\begin{array}{l}\text { Wheat, barley, teff, } \\
\text { potatoes }\end{array}$ & yes, some & 812 \\
\hline Imdibir & $\begin{array}{c}\text { Shoa } \\
\text { (Gurage) }\end{array}$ & Densely populated enset area. & $\begin{array}{l}\text { Enset, chat, coffee, } \\
\text { maize }\end{array}$ & $\begin{array}{l}\text { yes, } \\
\text { including } \\
\text { food }\end{array}$ & 2,205 \\
\hline Aze Deboa & $\begin{array}{c}\text { Shoa } \\
\text { (Kembata) }\end{array}$ & $\begin{array}{l}\text { Densely populated. Long tradition of } \\
\text { substantial seasonal and temporary migration. }\end{array}$ & $\begin{array}{l}\text { Enset, coffee, } \\
\text { maize, teff, } \\
\text { sorghum }\end{array}$ & $\begin{array}{l}\text { yes, } \\
\text { including } \\
\text { food }\end{array}$ & 1,509 \\
\hline Addado & $\begin{array}{l}\text { Sidamo } \\
\text { (Dilla) }\end{array}$ & $\begin{array}{l}\text { Rich coffee-producing area; densely } \\
\text { populated. }\end{array}$ & Coffee, enset & $\begin{array}{l}\text { yes, } \\
\text { including } \\
\text { food }\end{array}$ & 1,417 \\
\hline Gara Godo & $\begin{array}{l}\text { Sidamo } \\
\text { (Wolayta) }\end{array}$ & $\begin{array}{l}\text { Densely packed enset-farming area. Famine in } \\
\text { 1983/84. Malaria in mid1988. }\end{array}$ & Barley, enset & $\begin{array}{l}\text { yes, } \\
\text { including } \\
\text { food }\end{array}$ & 1,245 \\
\hline Doma & Gama Gofa & $\begin{array}{l}\text { Resettlement area (1985); semi-arid; } \\
\text { experienced droughts throughout the 1980s; } \\
\text { remote. }\end{array}$ & Enset, maize & yes, some & 1,150 \\
\hline
\end{tabular}

Source: Community survey ERHS, Bevan and Pankhurst (1996) and Dercon and Hoddinott (2004). 


\section{DESCRIPTIVES}

\section{Outcomes}

Consumption is defined as the sum of values of all food items, including purchased meals, and noninvestment nonfood items. The latter are interpreted in a limited way, so that contributions for durables and nondurables, as well as health and education expenditures, are excluded (Hentschel and Lanjouw 1996). Although there are good conceptual reasons for including use values for durables or housing (Deaton and Zaidi 2002), we do not do so here; the heterogeneity in terms of age and quality of durables owned by our respondents, together with the near complete absence of a rental market for housing, would make the calculation of use values highly arbitrary. Because comparisons of productive and consumer durable holdings between 1994 and 2004 show rising holdings of these durables, ${ }^{6}$ and comparisons of school enrollment data show significant increases in enrollment, ceteris paribus, our consumption estimates may understate the actual increases in household welfare and bias downward the estimated impacts of public investments on consumption and poverty. Consumption is expressed in peradult equivalent terms; see Dercon and Krishnan (2000) for the conversion factors used to express these. Lastly, it is deflated by a food price index, calculated as a Laspeyres index, based on local (PA) prices collected specifically for this purpose and using average expenditure shares in 1994 as the weights.

Estimating levels and changes in poverty requires first setting a poverty line. Here, we use a costof-basic-needs approach. Based on the 1994 data, a food poverty line is constructed using a bundle of food items that would provide 2,300 Kcals per adult, per day. To this, we add a nonfood bundle using the method set out in Ravallion and Bidani (1994). Dercon and Krishnan (1996, 2003) provide further information on the construction of the poverty line, including details of the food basket and its sensitivity to different sources of data on prices used to value the food basket.

Table 2 shows the evolution of these three outcome variables over time. In examining these, it is important to note that the seasonal timing of the rounds in 1995, 1999, and 2004 was approximately the same as that of the first 1994 round. However, the 1997 round was collected at a much different point of time in the agricultural year - the immediate postharvest period - and this seasonal consideration, together with the fact that 1997 was, in agricultural terms, atypically good, has the effect of making the 1997 outcomes look particularly high. Mindful of this, there is significant growth in real consumption between 1994 and 1999. Distributionally, this growth is pro-poor as evidenced by the reduction in headcount poverty from 48 to 36 percent in this period and a fall in the Gini coefficient for consumption (not shown) from 0.44 to 0.41 . However, these improvements slow after 1999. Median real per-adult equivalent consumption, which grew by 24 percent between 1994 and 1999, grows by only 9 percent in the following five years. Growth is less distributionally neutral, with mean consumption growth growing faster than median growth and with no change in the poverty headcount. ${ }^{7}$

\section{Public Investments: Trends at the Household Level}

Here, we explain how access to roads and extension are measured in the data available to us and how these have evolved over time.

The household survey instrument asked households how many times they had been visited by an extension agent during the last main cropping season. ${ }^{8}$ Using these data, we create a dummy variable equaling one if the household had received at least one such visit, and zero otherwise. As shown in Table 2 , the percentage of households receiving at least one visit from an extension agent triples over this 10-

\footnotetext{
${ }^{6}$ For example, the percentage of households reporting owning hoes rises from 59 to 79 percent, owning plows rises from 79 to 87 percent, and owning beds rises from 49 to 58 percent.

${ }^{7}$ These trends in poverty are very similar to those reported for the country as a whole in World Bank (2005, Figure 1.1, p. 10).

${ }^{8}$ Extension workers are now called Development Agents. Over time, the government of Ethiopia has been working toward having three agents available per PA.
} 
year period; this increase is widely distributed with 13 of the 15 villages recording an increase in the number of households receiving at least one visit. However, the starting level in 1994 - 5.6 percent - was low, and most of this improvement occurs between 1994 and 1999.

Table 2. The distribution of households in the Ethiopian Rural Household Survey, by agroecological zone

\begin{tabular}{rccccc}
\hline & & & Year & \\
\hline Mean real consumption per adult equivalent & $\mathbf{1 9 9 4}$ & $\mathbf{1 9 9 5}$ & $\mathbf{1 9 9 7}$ & $\mathbf{1 9 9 9}$ & $\mathbf{2 0 0 4}$ \\
$\begin{array}{r}(1994=100) \\
\text { Median real consumption per adult } \\
\text { equivalent (1994 =100) }\end{array}$ & 100 & 90 & 135 & 124 & 133 \\
Headcount (P0) poverty & 48 & 55 & 33 & 36 & 35 \\
Access to all-weather road (percentage) & 36 & 37 & 39 & 54 & 67 \\
Received at least one extension visit & 6 & 5 & 7 & 13 & 16 \\
(percentage) & & & & & \\
\hline
\end{tabular}

All households in this sample have access to some sort of road or path. However, the quality of road varies significantly, from all-weather roads suitable for vehicular traffic to mud tracks that at best can support foot traffic. As noted in the introduction, the benefits of roads are perceived to operate through four channels: reducing the costs of acquiring inputs; increasing output prices; reducing the impact of shocks; and permitting entry into new, more profitable activities. In the community questionnaires administered as part of these surveys, community representatives were asked to identify the closest town and the quality of the road leading to that town. The distance to the closest towns does not change over time, but the quality of these roads does change. Given this, we define road access as a dummy variable equaling one if the household has access to a road capable of supporting truck traffic (and therefore trade) and bus traffic (and therefore facilitating the movement of people) in both the rainy and dry seasons. As Table 2 shows, initial levels of access to all-weather roads was around 40 percent, with significant improvements being recorded between 1997 and 1999, and between 1999 and 2004. 


\section{MODEL AND RESULTS}

The primary focus of this paper is the impact of two forms of public investments - extension and roads on consumption growth and poverty. A starting point for our empirical modeling strategy is to recognize that we want to model a growth process as a function of changes in available technologies (via access to extension) and changes in capital stock (roads). A natural way of doing so is an empirical growth model that allows for transitional dynamics (Mankiw et al. 1992). We observe households $i(i=1, \ldots, N)$ across periods $\mathrm{t}(\mathrm{t}=0, \ldots, \mathrm{T})$. Growth rates for household $\mathrm{i}\left(\ln y_{i t}-\ln y_{i t-1}\right)$ are related to initial levels of income $\left(\ln y_{i t-1}\right)$. Let $\delta$ represent sources of growth common to all households and $\mathrm{X}$ reflect fixed characteristics of the household, such as location, that also affect growth. Other sources of growth from t- 1 to $t$ are exogenous levels of capital stocks (e.g., roads) and access to technologies (e.g., via extension) observed at $\mathrm{t}-1\left(k_{i t-1}\right)$, both of which are time varying. Lastly, while standard growth models do not allow for transitory shocks such as changes in rainfall and prices $\left(\ln R_{t}-\ln R_{t-1}\right)$, we know from previous work with our data (Dercon 2004; Dercon, Hoddinott, and Woldehanna 2005) that such events do have growth effects. One way of thinking about these events is that initial efficiency (the technological coefficient in the underlying production function) may be influenced by period-specific conditions (Temple 1999) that cause growth rates to deviate from long-term trend.

Mindful of the numerous reasons why one should be careful in applying this framework to any context, given the theoretical and empirical assumptions implied by this model (see the reviews by Temple 1999, or Durlauf and Quah 1998), and dropping the i subscripts, our basic model is

$$
\ln y_{t}-\ln y_{t-1}=\delta+\alpha \ln y_{t-1}+\beta \ln k_{t-1}+\gamma\left(\ln R_{t}-\ln R_{t-1}\right)+\lambda X
$$

However, before estimating Equation 1, there are a number of empirical issues that require consideration. We do not have evenly spaced observations over time. This can be thought of as a missing data problem - that is, how do we estimate Equation 1 when we are missing data for 1996, 1998, and 2000-2003? To see how this might affect our model, writing Equation 1 for growth between t-1 and t-2 gives

$$
\ln y_{t-1}-\ln y_{t-2}=\delta+\alpha \ln y_{t-2}+\beta \ln k_{t-2}+\gamma\left(\ln R_{t-1}-\ln R_{t-2}\right)+\lambda X
$$

Suppose now we only observe t-2 and t. Adding Equations 1 and 2 and dividing by 2 gives

$$
\begin{aligned}
& \quad\left(\ln y_{t}-\ln y_{t-2}\right) / 2=\delta+\alpha\left(\ln y_{t-1}+\ln y_{t-2}\right) / 2+\beta\left(\ln k_{t-1}+\ln k_{t-2}\right) / 2 \\
& +\gamma\left(\ln R_{t}-\ln R_{t-2}\right) / 2+\lambda X .
\end{aligned}
$$

The left side is the average growth rate. The right-hand side consists of a number of complicated terms, with the exception of the second-to-last term, which is the yearly average of the rainfall change (or the total change divided by 2). Extending this to $\mathrm{p}$ periods in between yields

$$
\begin{aligned}
& \left(\ln y_{t}-\ln y_{t-p}\right) / \mathrm{p}=\delta+\alpha\left(\ln y_{t-1}+\ldots+\ln y_{t-p}\right) / \mathrm{p}+\beta\left(\ln k_{t-1}+\ldots+\ln k_{t-p}\right) / \mathrm{p} \\
& +\gamma\left(\ln R_{t}-\ln R_{t-p}\right) / \mathrm{p}+\lambda X
\end{aligned}
$$

This presents problems for estimation for the lagged dependent variable, and all time-varying "level" variables (such as infrastructure at $\mathrm{k}$ ). However, if one is willing to assume that changes are relatively slow so that $\ln y_{i t-1} \approx \ln y_{i t-p}$ and similarly for $\mathrm{k}$, the p-period average is approximated by the initial level at $t-p$. Then the regression to be estimated is

$$
\left(\ln y_{t}-\ln y_{t-p}\right) / \mathrm{p}=\delta+\alpha \ln y_{t-p}+\beta \ln k_{t-p}+\gamma\left(\ln R_{t}-\ln R_{t-p}\right) / \mathrm{p}+\lambda X
$$


All changes are expressed in averages per period (divided by p), and all level variables remain as they are, defined at t-p. The constants (and the fixed effects) are not affected.

Our next step is to introduce a disturbance term, $\varepsilon_{i t}$, into Equation 5. $\varepsilon_{i t}$ has two parts, a timeinvariant component $\left(\mu_{i}\right)$ and a time-varying component $\left(v_{i t}\right)$. The time-invariant component can be thought of as capturing all characteristics of the village and household not observed by us, which do not change over time, while $v_{i t}$ is white noise disturbance. Including these yields

$$
\left(\ln y_{t}-\ln y_{t-p}\right) / \mathrm{p}=\delta+\alpha \ln y_{t-p}+\beta \ln k_{t-p}+\gamma\left(\ln R_{t}-\ln R_{t-p}\right) / \mathrm{p}+\lambda X+\varepsilon_{i t-p}
$$

This disturbance term introduces several complications. First, there are good a priori reasons to believe that $\mathrm{E}\left(\ln y_{t-p} \varepsilon_{i t-p}\right) \neq 0$. To see why, note that $\ln y_{t}$ reflects growth in $\ln y$ between periods $\mathrm{t}$ and $\mathrm{t}-1$, and that $\ln y_{t-1}$ reflects growth in $\ln y$ between periods t-1 and t-2. $\varepsilon_{i t-1}$ enters into the growth regression for $\left(\ln y_{t}-\ln y_{t-1}\right)$, and $\varepsilon_{i t-2}$ enters into the growth regression for $\left(\ln y_{t-1}-\ln y_{t-2}\right)$. If there is any serial correlation in the disturbance terms, then $\mathrm{E}\left(\varepsilon_{i t-1} \varepsilon_{i t-2}\right) \neq 0$, and so $\mathrm{E}\left(\ln y_{t-p} \varepsilon_{i t-p}\right) \neq 0$. Making matters worse, note that a standard question in estimates of models like Equation 6 is whether there is conditional convergence in the household data: a negative estimate for $\alpha$ would suggest convergence, allowing for underlying differences in the steady state. Unobserved village or household characteristics play a role in determining these steady states so that there is correlation between $\ln y_{t-p}$ and $\mu_{i}$ and therefore between $\ln$ $y_{t-p}$ and $\varepsilon_{i t-p}$. Second, as discussed in the introduction, $\mathrm{E}\left(k_{t-p} \varepsilon_{i t-p}\right) \neq 0$ because $\mathrm{E}\left(k_{t-p} \mu_{i}\right) \neq 0$. In the case of roads, it is simply not tenable to believe that they are randomly scattered across the countryside. In the case of extension, if government extension services are targeted to more productive areas - for example, based on unobserved land fertility or entrepreneurship - or if better farmers are seeking out extension agents, this would be reflected in our model by correlation between observed characteristics of these farmers, such as $k_{t-p}$ and $\ln y_{t-p}$, and their unobserved characteristics.

We address the correlations between $\ln y_{t-p}$ and $\mu_{i}$ and between $\ln y_{t-p}$ and $\varepsilon_{i t-p}$ by using an instrumental variables (IV) estimator. We do so using Generalized Methods of Moments (GMM) so that these estimates are both consistent and efficient (Wooldridge 2002). We instrument $\ln y_{t-p}$ using timevarying household characteristics observed at time t-p. These are log fertile land holdings, log number of adult equivalents, and log number of livestock units. Again thinking of the discussion of Solow-type growth models, these can be thought of as household characteristics that influence how close the household is to the steady state. In addition, we control for all time-invariant household characteristics (for example, initial levels of land, labor power, livestock, and human capital; the household's physical location; and so on) by using a household fixed effects estimator; specifically, we difference all left- and right-hand side components of Equation 6 by their means. ${ }^{9}$ In so doing, unobserved, time-invariant household characteristics are differenced out, as are the observed, time-invariant household characteristics, $X$. There are three additional advantages of this approach. First, should there be any attrition bias brought about by the influence of time-invariant household characteristics on attrition, household fixed effects estimation will also address this. Second, the use of IV will reduce attenuation bias from measurement error in the regressors. Finally, standard errors are robust to heteroscedasticity of unknown form.

\section{Basic Results}

Table 3 presents the results of estimating Equation 6 for growth in consumption and whether the household is poor. The latter outcome is not, strictly speaking, a direct product of a growth regression. Rather, it can be thought of as an extension of the consumption growth regressions. Although these growth regressions show the average effect of public investments across the whole sample, the poverty

\footnotetext{
${ }^{9}$ For the dependent variable, we calculate the mean first difference in growth rates by household. Our dependent variable is the first difference in growth rates minus the mean first difference in growth rates.
} 
regressions give us insights into the distributional effects of these investments - specifically whether they are of sufficient magnitude to pull poor households out of poverty.

Table 3. Determinants of consumption growth and poverty status: Basic results

\begin{tabular}{|c|c|c|c|c|}
\hline & Poor & Poor & $\begin{array}{l}\text { Consumption } \\
\text { Growth }\end{array}$ & $\begin{array}{l}\text { Consumption } \\
\text { Growth }\end{array}$ \\
\hline & (1) & (2) & (3) & (4) \\
\hline $\begin{array}{l}\text { Lagged endogenous variables }{ }^{1-4} \\
\text { Log consumption }\end{array}$ & $\begin{array}{c}-0.147 \\
(3.67) * *\end{array}$ & $\begin{array}{c}-0.131 \\
(3.30)^{* *}\end{array}$ & $\begin{array}{c}-0.376 \\
(9.43)^{* *}\end{array}$ & $\begin{array}{c}-0.396 \\
(10.10)^{* *}\end{array}$ \\
\hline $\begin{array}{l}\text { Public investments } \\
\text { Received visit from extension officer } \\
\text { Access to all-weather road }\end{array}$ & $\begin{array}{l}-0.095 \\
(2.48)^{* *} \\
-0.069 \\
(2.17)^{* *}\end{array}$ & $\begin{array}{c}-0.098 \\
(2.57)^{* *} \\
-0.069 \\
(2.18)^{* *}\end{array}$ & $\begin{array}{c}0.059 \\
(1.59) \\
0.166 \\
(5.42)^{* *}\end{array}$ & $\begin{array}{c}0.071 \\
(1.96)^{* *} \\
0.163 \\
(5.34)^{* *}\end{array}$ \\
\hline $\begin{array}{r}\text { Other controls } \\
\text { Rainfall shocks } \\
\text { Output price shocks }\end{array}$ & & $\begin{array}{c}-0.027 \\
(0.82) \\
0.092 \\
(4.97)^{* *}\end{array}$ & & $\begin{array}{c}0.118 \\
(3.12)^{* *} \\
-0.172 \\
(7.59)^{* *}\end{array}$ \\
\hline $\begin{array}{r}\text { Input price shocks } \\
\text { Death shocks } \\
\text { Illness shocks }\end{array}$ & & $\begin{array}{l}-0.053 \\
(0.47) \\
0.077 \\
(1.08) \\
0.083 \\
(1.00)\end{array}$ & & $\begin{array}{c}-0.117 \\
(1.01) \\
-0.162 \\
(2.08)^{* *} \\
-0.109 \\
(1.22)\end{array}$ \\
\hline $\begin{array}{r}\text { Diagnostic statistics } \\
\text { Kleibergen-Paap rank Wald F statistic } \\
\text { Hansen J test } \\
\text { Sample size }\end{array}$ & $\begin{array}{c}90.10 * * \\
0.82 \\
4781\end{array}$ & $\begin{array}{c}88.13^{* *} \\
0.88 \\
4771\end{array}$ & $\begin{array}{c}90.10^{* *} \\
4.68 \\
4771\end{array}$ & $\begin{array}{c}88.13^{* *} \\
4.56 \\
4771\end{array}$ \\
\hline
\end{tabular}

Notes:

1. Lagged endogenous variables are expressed in real per-adult equivalent terms. 2. Instruments for lagged endogenous variables are lagged log livestock units per adult equivalent, lagged log number of adult equivalents and lagged log cultivable land per adult equivalent. 3. A dummy variable if survey conducted in postharvest period is included in all specifications but not reported. 4. Absolute values of $\mathrm{z}$ statistics in parentheses. 5. * significant at $10 \%$ level; ** significant at $5 \%$ level.

The first and third columns provide a basic set of results that exclude the impacts of rainfall and other shocks - in other words, growth models without allowances for transitory shocks. These show that receiving at least one visit from an agricultural extension officer reduces poverty by 9.5 percentage points, and access to good roads reduces the likelihood that a household is poor by 6.9 percentage points. Receiving a visit from an agricultural extension officer boosts consumption growth by 5.9 percent, though this is not statistically significant; access to good roads increases consumption growth by 16.6 percent.

The second and fourth columns report estimates of these models with a set of time-varying shocks included as additional controls. The first of these, rainfall shocks, is the log change in annual rainfall since the previous survey round. The next, output price shocks, is a weighted average of median output prices for the main crops grown in each PA by round. We started by calculating the average price received by farmers who sold any output for each of the following crops - maize, barley, wheat, black teff, white teff, enset, chat, coffee, and sorghum - in the period between the harvesting of those crops and the survey. (Harvesting typically took place four to six months prior to the survey.) For each village and round, we constructed the median price for each crop. We then constructed a weighted average of these 
medians, where the weights were based on the share of production (in value terms) of each crop. The last three are household self-reports of input price, death, and illness "shocks" that, when occurred, led to reductions in household income or consumption or led to asset losses. ${ }^{10}$ This model includes all components of the growth regression described by Equation 6 and thus represents our preferred specification.

We begin by considering the results of the specification tests associated with our results. The first-stage F statistic and the Kleibergen-Paap (2006) F statistic (a generalized version of the F statistic suggested by Stock and Yugo (2004), but one that is robust to heteroscedasticity) provide information on the relevance of the variables used to instrument the endogenous lagged dependent variable. Where lagged log consumption is treated as endogenous, these test statistics indicate that we have good instruments in the relevance sense; using Table 1 of Stock and Yugo (2004) as a guide, with 95 percent confidence, our IV estimates have less than 5 percent of OLS bias. The Hansen J test is an overidentification test. It shows that we cannot reject the null that our instruments can be excluded from the second-stage regressions for consumption growth and poverty despite the fact that, as Baum, Shaffer, and Stillman (2003) and Hoxby and Paserman (1998) note, this test tends to over-reject this null in presence of intracluster correlation. ${ }^{11}$

The results in columns 3 and 4 are nearly identical to those reported in columns 1 and 2, with the notable exception that the impact of extension on consumption growth is now significant at the 5 percent level. Improvements in access to good roads and the receipt of at least one visit by an extension agent reduce poverty by meaningful amounts (6.9 and 9.8 percentage points, respectively) and increase consumption growth by 16.3 and 7.1 percent, respectively.

\section{Robustness Checks}

Table 4 shows the results of a series of robustness checks designed to assess whether changes in model specification, estimation, or sample affect these core results.

Although GMM estimates are both consistent and efficient, they are vulnerable to the influence of outliers because the optimal weighting matrix that underpins them is a function of fourth moments (Baum, Shaffer, and Stillman 2003; Hayashi 2000). We address this concern in two ways. First, we report the results of 1 percent trim estimates that drop the top and bottom 1 percent of observations of consumption growth. Second, we use a limited information maximum likelihood (LIML) estimator that is not vulnerable to this concern and has the added advantage of being a superior estimator when instruments are weak (see Stock and Yugo 2004, p. 31). Doing so has no meaningful effect on the regressions on consumption growth or poverty status.

Row 3 explores how sensitive the results are to changes in model specification, specifically the inclusion of additional time-varying household characteristics. For example, over the 10 -year period of this panel, it is reasonable to expect that mean indicators of consumption might rise if households are accumulating assets. If this is the case, then our results may be capturing a spurious correlation. Row 3 reports results when three additional characteristics of the household - lagged log age of head, lagged average number of grades of schooling of household members older than 15, and lagged sex of head - are included as additional determinants of growth and poverty status. Generally, these do not lead to major changes in parameter estimates or significance. This is also true if we try other specifications not reported

\footnotetext{
${ }^{10}$ See Dercon, Hoddinott, and Woldehanna (2005) for a detailed description.

${ }^{11}$ GMM standard errors are robust to heteroscedasticity of unknown form. However, Moulton (1990, p. 334) has noted, "It is reasonable to expect that units sharing an observable characteristic, such as industry or location, also share unobservable characteristics that would lead the regression disturbances to be correlated.” These correlations, if positive, may cause the estimated standard errors to be biased downward. In the statistics literature, this issue is referred to as the design effect; see Kish (1965) and Deaton (1997). While it is possible to correct for this intracluster correlation, work by Angrist and Lavy (2002) and Wooldridge (2003), suggests that doing so here would be invalid because we have only a relatively small number of clusters. For this reason, we have not reported cluster robust standard errors here. As a check, however, we did reestimate columns 3 and 4 with this correction. It made no substantive difference to the results for consumption growth or poverty.
} 
here, such as replacing livestock units with livestock values in the instrument set, adding other public investments such as access to piped water, or adding lagged rain as an additional instrument.

Table 4. Selected robustness checks on basic results

\begin{tabular}{|c|c|c|c|c|c|}
\hline \multirow{2}{*}{\multicolumn{2}{|c|}{ Specification }} & \multicolumn{2}{|c|}{ Poor } & \multicolumn{2}{|c|}{ Growth in Consumption } \\
\hline & & $\begin{array}{l}\text { Received visit } \\
\text { from extension } \\
\text { officer }\end{array}$ & $\begin{array}{l}\text { Access to all- } \\
\text { weather road }\end{array}$ & $\begin{array}{l}\text { Received visit } \\
\text { from extension } \\
\text { officer }\end{array}$ & $\begin{array}{l}\text { Access to all- } \\
\text { weather road }\end{array}$ \\
\hline \multirow[t]{2}{*}{ (0) } & Basic results & -0.098 & -0.069 & 0.071 & 0.163 \\
\hline & & $(2.57)^{* *}$ & $(2.18)^{* *}$ & $(1.96)^{* *}$ & $(5.34)^{* *}$ \\
\hline \multirow[t]{2}{*}{ (1) } & $1 \%$ trim of dependent variables & -0.096 & -0.070 & 0.062 & 0.165 \\
\hline & & $(2.47)^{* *}$ & $(2.19)^{* *}$ & $(1.79)^{*}$ & $(6.21)^{* *}$ \\
\hline \multirow[t]{2}{*}{$(2)$} & LIML estimation & -0.096 & -0.069 & 0.069 & 0.164 \\
\hline & & $(2.55)^{* *}$ & $(2.19)^{* *}$ & $(1.91)^{*}$ & $(5.38)^{* *}$ \\
\hline \multirow[t]{2}{*}{ (3) } & Include additional characteristics & -0.110 & -0.060 & 0.071 & 0.156 \\
\hline & of household and head & $(2.86)^{* *}$ & $(1.83)^{*}$ & $(1.95)^{*}$ & $(4.93)^{* *}$ \\
\hline \multirow[t]{2}{*}{ (4) } & Instrument access to extension & -0.504 & -0.063 & 0.423 & 0.158 \\
\hline & & $(2.10)^{* *}$ & $(1.97)^{* *}$ & $(2.31)^{* *}$ & $(5.18)^{* *}$ \\
\hline \multirow[t]{2}{*}{ (5) } & Drop output shocks & -0.098 & -0.067 & 0.072 & 0.159 \\
\hline & & $(2.55)^{* *}$ & $(2.11)^{* *}$ & $(1.92)^{*}$ & $(5.15)^{* *}$ \\
\hline \multirow[t]{2}{*}{ (6) } & Reduced form regression & -0.115 & -0.061 & 0.046 & 0.177 \\
\hline & & $(3.25)^{* *}$ & $(1.90)^{*}$ & $(1.00)$ & $(4.20)^{* *}$ \\
\hline \multirow[t]{2}{*}{ (7a) } & Village fixed effects & -0.059 & -0.090 & - & - \\
\hline & & $(2.19) * *$ & $(2.71) * *$ & & \\
\hline \multirow[t]{2}{*}{ (7b) } & Instrumental variables probit with & -0.164 & -0.254 & - & - \\
\hline & village fixed effects & $(2.15)^{* *}$ & $(2.71)^{* *}$ & & \\
\hline
\end{tabular}

Specification notes:

(0): Reports, for purposes of comparison, results found in columns 3 and 4 of Table 3. (1): Reports 1\% trim estimates that drop the top and bottom $1 \%$ of observations of consumption growth (for growth in consumption and poverty status); (2) Reports results of using Limited Information Maximum Likelihood (LIML) estimation rather than GMM; (3) Reports results when additional characteristics of the household (lagged average number of grades of schooling of household members older than 15) and lagged sex of head are included as additional determinants of growth and poverty status; (4) Reports results when "received visit from extension officer" is treated as endogenous and instrumented by number of extension offices within PA; (5) Output shocks dropped from specification; (6) Reports results of estimated reduced form fixed effects regression when endogenous dummy variables are dropped and their instruments included; and (7) Comparison of village fixed effects results (7a) with lagged consumption treated as endogenous and (7b) with an instrumental variables probit with village fixed effects. For additional notes, see Table 3.

Next, we consider the impact of also treating access to extension as endogenous. While our estimation strategy controls for many observable and unobservable factors that might otherwise be correlated with access to extension - including time-invariant household characteristics and time-varying household shocks - it still might be possible that there is some unobserved, time-varying household characteristic correlated with access to extension. To do so, we add an additional instrumental variable: the number of agricultural extension officers available within the PA. When we do so, results from the first-stage F statistic and the Cragg-Donald F statistics again indicate that we have strong instruments for the consumption growth and poverty regressions. Also as before, our Hansen J test results indicate that we satisfy the uncorrelatedness condition for the consumption growth and poverty results. Mindful of these test statistics, the results reported in row 4 indicate that, when instrumented, the coefficient on extension increases dramatically. Because the number of agricultural extension officers changes only slowly over time - and in some localities does not change at all - it is possible that these results are picking up a local treatment effect (LATE) as opposed to an average treatment effect over the full sample (Imbens and Angrist 1994; Card 2001). For this reason, we are cautious about taking the results shown in 
row 5 at face value. What they do suggest, however, is that our estimates of the impact of visits by extension services are conservative.

Our model specification includes output price shocks as measured by changes in village-level prices. Arguably, these might be correlated with the time-varying component of the error term and thus generating biased parameter estimates. As a check, we re-estimate these two models, dropping output price shocks. Our results, found in row 5 , are virtually unchanged, indicating that this is not a significant concern.

Row 6 reports the results of estimating our growth and poverty models as reduced forms, fixed effects regression when endogenous dummy variables are dropped and their instruments included in their place. The impact of access to roads is unchanged in these regressions, as is the impact of access to extension on poverty status. Access to extension continues to reduce poverty; however, the magnitude of its effect on consumption growth is slightly smaller than in the IV regressions, and the parameter estimate is no longer statistically significant. ${ }^{12}$

The poverty status regressions are estimated as linear probability models. Although it is technically feasible to estimate logit models with household fixed effects, doing so carries several costs. First, the estimation of these automatically drops all observations where poverty status does not change, leading to a selected sample. We cannot use GMM, so estimates derived from these models are not fully efficient and the estimated coefficients are not readily interpretable in terms of their marginal effects. Given this, we have followed the lead of de Janvry, Finan, Sadoulet, and Vakis (2006) and Hyslop (1999) and used a linear probability model. As a check on the poverty results, we also estimated a probit regression for poverty status, treating lagged consumption as endogenous, including additional household characteristics (age, sex, and education of the head) as additional regressors and controlling for villagelevel fixed effects. Because this estimator is not strictly comparable to our earlier results, we also estimate a linear probability model using GMM with the same regressors as the probit, again controlling for village - not household - fixed effects. The village fixed effects linear probability model is reported in row 7a; the marginal effects derived from the instrumental variables probit are reported in row 7b. Comparing these, we see that the probits generate higher estimates of impact, suggesting our approach is conservative.

Finally, we have assumed that patterns of growth are the same for all households. This is a strong assumption, which if incorrect would imply that our model is misspecified. In Tables 5 and 6, we relax this assumption and reestimate our model based on different disaggregations derived from different initial household characteristics. There is some suggestion in these results of differing effects by initial characteristics. For example, extension visits appear to have a larger effect on poverty for younger household heads and literate household heads. Improvements in road quality seem to have a more marked effect on consumption growth of households that initially were wealthier. However, as a check on these results, we reestimated the models reported in Table 3, columns 2 and 4, but included as additional regressors interaction terms between these different household characteristics and access to extension and all-weather roads. The last rows of Tables 5 and 6 report the F statistic on the joint significance of these interaction terms, showing in all cases but one (literacy in the consumption growth regressions) that we cannot reject the null hypothesis that these interaction terms are not significantly different from zero. This suggests that our results are not adversely affected by the assumption of homogenous patterns of growth across the sample.

\footnotetext{
${ }^{12}$ We also undertook two additional robustness checks not reported in Table 4. First, we included a full set of survey round by village dummy variables as additional regressors. While doing so carries a cost - we can no longer identify the effect of changes in road quality - it does allow us to assess whether the impact of extension is robust to a full set of fixed and timevarying locality controls. When we do so, we obtain a coefficient on extension that is only slightly lower than that reported in Tables 3 and 4, suggesting that the results of extension are robust even with the inclusion of these additional controls. Second, we interacted selected household characteristics observed at the start of the survey - land holdings and literacy - with access to improved roads and extension to see whether the impact of these public services varied by household type. We find some evidence of interaction effects - land size interacted with road quality and literacy interacted with access to extension both have positive coefficients - but the probability values associated with these coefficients tend to hover around 0.10-0.15.
} 
Table 5. Impact of extension and all-weather roads on poverty by initial household characteristics

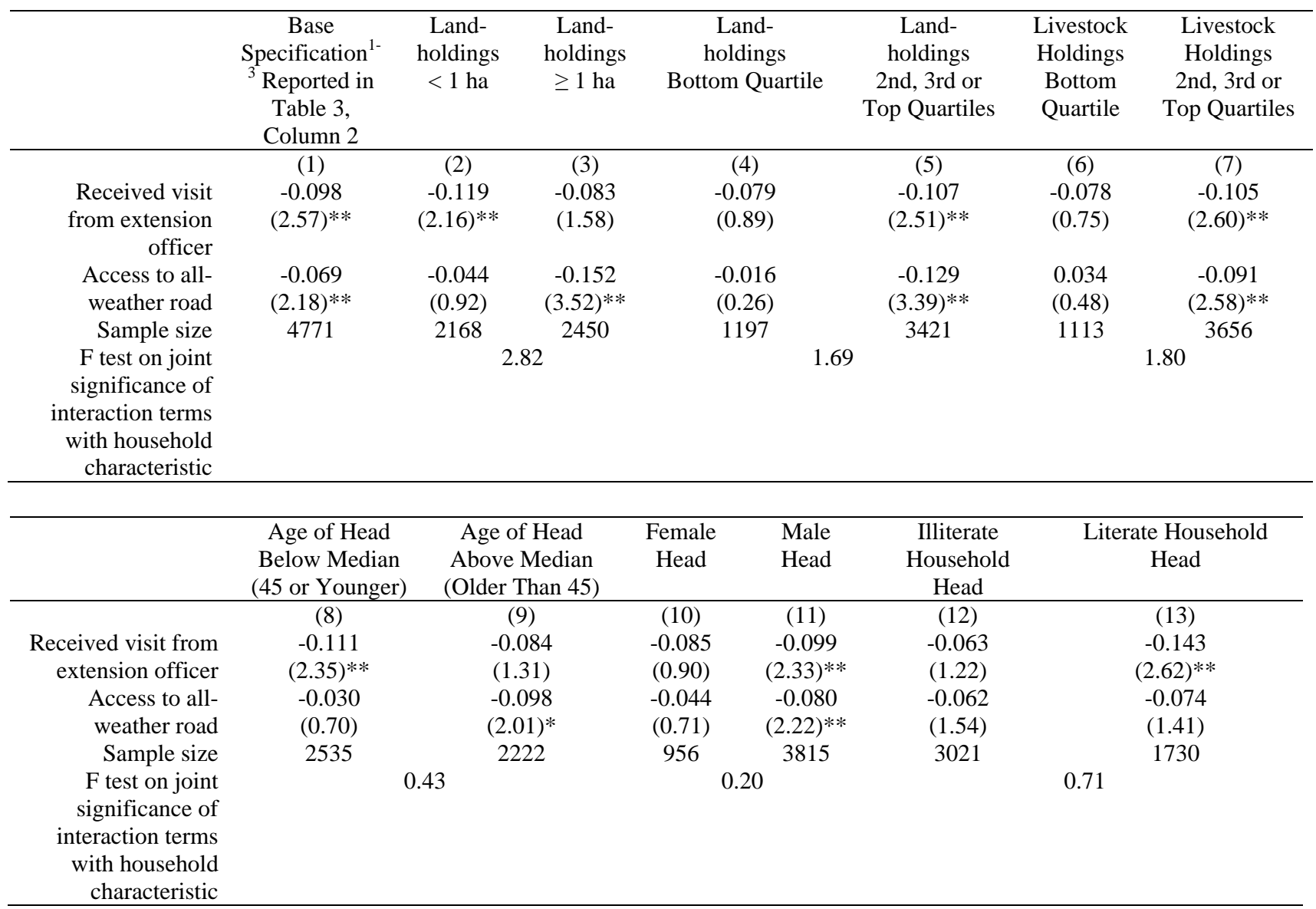

Notes: 1. Disaggregations are based on initial household characteristics. F tests are generated from models reported in Table 3, columns 2 and 4, with interaction terms between these initial household characteristics and extension and access to all-weather roads. 2. Absolute values of z statistics in parentheses. * significant at $10 \%$ level; ** significant at $5 \%$ level. 3 . For additional details, see notes to Table 3.

Table 6. Impact of extension and all-weather roads on consumption growth by initial household characteristics

\begin{tabular}{|c|c|c|c|c|c|c|c|}
\hline & $\begin{array}{c}\text { Base } \\
\text { Specification } \\
\text { Reported in } \\
\text { Table 3, } \\
\text { Column } 4\end{array}$ & $\begin{array}{l}\text { Land- } \\
\text { holdings } \\
<1 \text { ha }\end{array}$ & $\begin{array}{l}\text { Land- } \\
\text { holdings } \\
\geq 1 \text { ha }\end{array}$ & $\begin{array}{c}\text { Land- } \\
\text { holdings } \\
\text { Bottom Quartile }\end{array}$ & $\begin{array}{l}\text { Land- } \\
\text { holdings } \\
\text { 2nd, 3rd or } \\
\text { Top } \\
\text { Quartiles }\end{array}$ & $\begin{array}{l}\text { Livestock } \\
\text { Holdings } \\
\text { Bottom } \\
\text { Quartile }\end{array}$ & $\begin{array}{l}\text { Livestock } \\
\text { Holdings } \\
\text { 2nd, 3rd or } \\
\text { Top } \\
\text { Quartiles }\end{array}$ \\
\hline & $(1)$ & (2) & (3) & (4) & (5) & (6) & $(7)$ \\
\hline Received visit from & 0.071 & 0.078 & 0.075 & 0.140 & 0.076 & 0.031 & 0.080 \\
\hline extension officer ${ }^{1-3}$ & $(1.91)^{*}$ & $(1.40)$ & (1.55) & $(1.32)$ & $(2.00)^{* *}$ & $(0.31)$ & $(2.10)^{* *}$ \\
\hline Access to all-weather & 0.159 & 0.136 & 0.249 & 0.174 & 0.206 & 0.078 & 0.181 \\
\hline road & $(5.14)^{* *}$ & $(2.54)^{* *}$ & $(7.40)^{* *}$ & $(2.59) * *$ & $(5.85) * *$ & $(1.04)$ & $(5.42) * *$ \\
\hline Sample size & 4771 & 2166 & 2147 & 1196 & 3417 & 1112 & 3651 \\
\hline $\begin{array}{r}\text { F test on joint } \\
\text { significance of } \\
\text { interaction terms with } \\
\text { household } \\
\text { characteristic }\end{array}$ & & \multicolumn{2}{|c|}{4.30} & \multicolumn{2}{|c|}{2.71} & \multicolumn{2}{|c|}{0.77} \\
\hline
\end{tabular}


Table 6. Continued

\begin{tabular}{|c|c|c|c|c|c|c|}
\hline & $\begin{array}{c}\text { Age of Head } \\
\text { Below Median } \\
\text { (45 or Younger) } \\
\end{array}$ & $\begin{array}{c}\text { Age of Head } \\
\text { Above Median } \\
\text { (Older Than 45) } \\
\end{array}$ & $\begin{array}{c}\text { Female } \\
\text { Head }\end{array}$ & $\begin{array}{l}\text { Male } \\
\text { Head }\end{array}$ & $\begin{array}{c}\text { Illiterate } \\
\text { Household } \\
\text { Head }\end{array}$ & $\begin{array}{c}\text { Literate } \\
\text { Household Head }\end{array}$ \\
\hline & $(8)$ & (9) & $(10)$ & (11) & $(12)$ & (13) \\
\hline Received visit from & 0.115 & 0.021 & 0.071 & 0.075 & 0.014 & 0.149 \\
\hline extension officer & $(2.55)^{* *}$ & $(0.35)$ & $(0.77)$ & $(1.86)^{*}$ & $(0.33)$ & $(2.82)^{* *}$ \\
\hline Access to all-weather road & 0.118 & 0.207 & 0.196 & 0.157 & 0.138 & 0.197 \\
\hline & $(3.11)^{* *}$ & $(4.14)^{* *}$ & $(2.79)^{* *}$ & $(4.73)^{* *}$ & $(3.35)^{* *}$ & $(4.57)^{* *}$ \\
\hline Sample size & 2532 & 2219 & 973 & 3812 & 3015 & 1730 \\
\hline $\begin{array}{l}\text { F test on joint significance } \\
\text { of interaction terms with } \\
\text { household characteristic }\end{array}$ & \multicolumn{2}{|c|}{0.43} & \multicolumn{2}{|c|}{0.04} & & $4.52 *$ \\
\hline
\end{tabular}

Notes: 1 . Absolute values of $\mathrm{z}$ statistics in parentheses. $2 .{ }^{*}$ significant at $10 \%$ level; ** significant at $5 \%$ level. 3 . For additional details, see notes to Table 5 .

\section{Further Discussion}

The results presented here give estimates of the impact of public investments that lead to better roads and greater access to extension services. They do not tell us why we observe these effects. There is other data in the ERHS that can help address this question.

Better roads in these localities make it easier for households to access local market towns that in turn are linked to larger urban centers. Dercon and Hoddinott (2005) document the myriad economic links between these survey sites and market towns. They show that in 2004, roughly half of households purchasing inputs for crops in the meher (long rain) and belg (short rain) seasons do so in local market towns. About 40 percent of households purchase inputs for livestock such as feed in these localities. For four crops grown widely in this sample (teff, wheat, maize, and eucalyptus), there is considerable variation in location of sale, ranging from 24 percent (eucalyptus) to 59 percent (wheat) being sold in local market towns. Most notably, the vast majority of livestock and livestock products are sold in the local market towns. Artisanal products made by villagers (particularly by women) such as handicrafts are typically sold in local market towns. Lastly, more than half of the purchases of goods for consumption occur in local market towns. Dercon and Hoddinott (2005) also show that improvements in road quality increase the likelihood of purchasing crop inputs (by 29 to 34 percent, depending on the season) and, for women, of selling artisanal products (by 39 percent).

Understanding why agricultural extension has positive impacts is trickier because, apart from the 1999 survey round, we have little direct information on exactly what information is imparted by agents to farmers. The 1999 survey asked farmers to describe the two most important activities of extension agents. Acting as a source of information about the usage of modern inputs was ranked by 62 percent of respondents as being the most important activity, and a further 10 percent of respondents listed this as their second most important activity. Serving as a source of knowledge about new cultivation practices was listed by 16 percent of farmers as the most important activity of extension agents, and 46 percent listed this as their second most important activity. Furthermore, among households using a modern input such as fertilizer, 56 percent reported that they were encouraged to do so by extension agents. We also computed Pearson correlation coefficients for the use of fertilizer and receipt of at least one visit by an extension agent. In 1994, this relationship was weak, with the Pearson correlation coefficient equaling 0.07. However, by 2004 this association appeared much stronger, with the Pearson correlation coefficient equaling 0.27 and being significant at the 1 percent level. In related work, Bachewe, Hoddinott, and Pardey (2008) apply stochastic frontier analysis to these panel data, finding that both fertilizer applications and access to extension have played a role in reducing productive inefficiency. Given this, drawing implications of our results on agricultural extension should be done cautiously. Some of the effect may represent transfers of technology or knowledge, and some of the effect may reflect the influence that extension agents have in terms of increased use of fertilizer and other inputs. 


\section{CONCLUSIONS}

Public investments have the potential to play important roles in facilitating increased growth and faster poverty reduction. In this paper we have investigated whether two forms of public investment have played such a role in rural Ethiopia. Using longitudinal household data, we find that public investments that led to improvements in road quality and increased access to agricultural extension services led to faster consumption growth and lower rates of poverty. The magnitudes of these effects are meaningful, though the interpretation of the findings regarding extension should be done with caution. Receiving at least one extension visit reduces headcount poverty by 9.8 percentage points and increases consumption growth by 7.1 percent. Access to all-weather roads reduces poverty by 6.9 percentage points and increases consumption growth by 16.3 percent. These results are robust to changes in model specification and estimation methods. These results are obtained using an estimator that accounts for all fixed household characteristics as well as the impact of transitory shocks. The results for consumption growth and poverty are robust to changes in model specification and estimation methods. 


\section{REFERENCES}

Anderson, J., and G. Feder. 2007. “Agricultural extension.” In R. Evenson and P. Pingali (eds.), Handbook of Agricultural Economics Vol 4, Amsterdam: Elsevier-North Holland.

Angrist, J., and V. Lavy. 2002. "The effect of high school matriculation awards: Evidence from randomized trials." Cambridge, MA: National Bureau of Economic Research Working Paper 9389.

Bachewe, F., J. Hoddinott, and P. Pardey. 2008. "Sources of inefficiency and growth in agricultural output in subsistence agriculture: A stochastic frontier analysis of fifteen ethiopian villages.” Mimeo. Department of Applied Economics, University of Minnesota.

Baum, C., M. Shaffer, and S. Stillman. 2003. "Instrumental variables and GMM: Estimation and testing.” Department of Economics, Boston College Working paper 545.

Bevan, P., and A. Pankhurst. 1996. "Report on the sociological dimensions of the Ethiopian Rural Economies Project.” Unpublished, Centre for the Study of African Economies, Oxford University.

Birkhaeuser, D., R. Evenson, and G. Feder.1991. "The economic impact of agricultural extension: A review.” Economic Development and Cultural Change 39(3): 507-521.

Card, D. 2001. "Estimating the return to schooling: Progress on some persistent econometric problems." Econometrica 69: 1127-1160.

Deaton, A. 1997. The analysis of household surveys: A microeconometric approach to development policy. Baltimore and London: The Johns Hopkins University Press for the World Bank.

Deaton, A., and S. Zaidi. 2002. “Guidelines for constructing consumption aggregates for welfare analysis.” Living Standards Measurement Study Working Paper: 135, Washington, D.C.: The World Bank.

de Janvry, A., F. Finan, E. Sadoulet, and R. Vakis. 2006. "Can conditional cash transfer programs serve as safety nets in keeping children at school and from working when exposed to shocks?” Journal of Development Economics 79(2): 349-373.

Dercon, S. 2004. "Growth and shocks: Evidence from rural Ethiopia.” Journal of Development Economics 74(2): 309-329.

Dercon, S. 2006. “Economic Reform, Growth and the Poor: Evidence from Rural Ethiopia.” Journal of Development Economics 81(1): 1-24.

Dercon, S., and J. Hoddinott. 2004. “The Ethiopian Rural Household Surveys: Introduction.” Unpublished, International Food Policy Research Institute, Washington, D.C.

Dercon, S., and J. Hoddinott. 2005. "Livelihoods, growth, and links to market towns in 15 Ethiopian villages." FCND Discussion Paper 194, International Food Policy Research Institute, Washington DC.

Dercon, S., J. Hoddinott, and T. Woldehanna. 2005. "Consumption and shocks in 15 Ethiopian Villages, 19992004.” Journal of African Economies, 14: 559-585.

Dercon, S., and P. Krishnan. 1996. “A consumption based measure of poverty in Ethiopia: 1989-1994.” In M. Taddesse and B. Kebede, Poverty and Economic Reform in Ethiopia, Proceedings Annual Conference of the Ethiopian Economics Association.

Dercon, S., and P. Krishnan. 2000. "Vulnerability, poverty and seasonality in Ethiopia.” Journal of Development Studies 36(6): 25-53.

Dercon S., and P. Krishnan. 2003. “Changes in poverty in rural Ethiopia 1989-1995” in A. Booth and P. Mosley (eds.), The New Poverty Strategies. London: Palgrave MacMillan.

Durlauf, S., and D. Quah. 1998. The new empirics of economic growth. CEP Discussion paper 384.

Evenson, R. 2001. "Economic impacts of agricultural research and extension.” In B. Gardner and G. Rausser (eds.), Handbook of Agricultural Economics Vol 1A, Amsterdam: Elsevier-North Holland. 
Fan, S., and C. Chan-Kang. 2005. Road development, economic growth, and poverty reduction in China. IFPRI Research Report 138, International Food Policy Research Institute, Washington, D.C.

Fan, S., P. Hazell, and S. Thorat. 2000. "Government spending, agricultural growth and poverty in rural India.” American Journal of Agricultural Economics 82(4): 1038-1051.

Fan, S., L. Zhang, and X. Zhang. 2002. Growth, inequality and poverty in rural China: The role of public investments. IFPRI Research Report 125, International Food Policy Research Institute, Washington, D.C.

Hayashi, F. 2000. Econometrics. Princeton University Press, Princeton NJ.

Hentschel, J., and P. Lanjouw. 1996. "Constructing an indicator of consumption for the analysis of poverty: Principles and illustrations with reference to Ecuador.” Living Standards Measurement Study Working Paper: 124, Washington, D.C.: The World Bank.

Hoxby, C., and M. Paserman. 1998. “Overidentification tests with grouped data.” Cambridge, MA: National Bureau of Economic Research Technical Paper 223.

Hyslop, D. 1999. "State dependence, serial correlation, and heterogeneity in intertemporal labor force participation of married women.” Econometrica 67(6): 1255-1294.

Imbens, G., and J. Angrist. 1994. "Identification and estimation of local average treatment effects." Econometrica 62: 467-476.

Jacoby, H. 2000. “Access to markets and the benefits of rural roads.” Economic Journal 110(465): 713-737.

Jalan, J., and M. Ravallion. 2002, "Geographic poverty traps? A micro model of consumption growth in rural China.” Journal of Applied Econometrics 17(4): 329-346.

Kish, L. 1965. Survey Sampling. New York: John Wiley \& Sons.

Kleibergen, F., and R. Paap. 2006. “Generalized reduced rank tests using the singular value decomposition.” Journal of Econometrics 133(1): 97-126.

Mankiw, G., D. Romer, and D. Weil. 1992. “A contribution to the empirics of growth.” Quarterly Journal of Economics 107: 409-437.

Mogues, T., G. Ayele, and Z. Paulos. 2007. "The Bang for the Birr: Public Expenditures and Rural Welfare in Ethiopia.” IFPRI Discussion Paper 702, International Food Policy Research Institute, Washington, D.C.

Moulton, B. 1990. "An illustration of a pitfall in estimating the effects of aggregate variables on micro units." Review of Economics and Statistics 72(2): 334-338.

Ravallion, M., and B. Bidani. 1994. "How robust is a poverty profile?” World Bank Economic Review 8(1): 75-102.

Rosenzweig, M., and K. Wolpin. 1986. "Evaluating the effects of optimally distributed public programs.” American Economic Review 76(3): 470-487.

Stock, J., and M. Yugo. 2004. Testing for weak instruments in linear IV regression. Unpublished, Department of Economics, Harvard University.

Temple, J. 1999. “The new growth evidence.” Journal of Economic Literature 37(1): 112-156.

World Bank. 2005. Poverty and well-being: The role of agriculture and shocks. Washington, D.C.: World Bank.

Wooldridge, J. 2002. Econometric analysis of cross section and panel data. Cambridge, MA: MIT Press.

Wooldridge, J. 2003. “Cluster-sample methods in applied econometrics.” American Economic Review Papers and Proceedings 93(2): 133-138. 





\section{RECENT IFPRI DISCUSSION PAPERS}

\section{For earlier discussion papers, please go to www.ifpri.org/pubs/pubs.htm\#dp. All discussion papers can be downloaded free of charge.}

839. The impact of Ethiopia's Productive Safety Net Programme and its linkages. Daniel O. Gilligan, John Hoddinott, and Alemayehu Seyoum Taffesse, 2008.

838. Aid effectiveness and capacity development: Implications for economic growth in developing countries. Prabuddha Sanyal and Suresh Babu, 2008.

837. A two-dimensional measure of polarization. Tewodaj Mogues, 2008.

836. Higher fuel and food prices: Economic impacts and responses for Mozambique. Channing Arndt, Rui Benfica, Nelson Maximiano, Antonio M.D. Nucifora, and James T. Thurlow, 2008

835. Accelerating innovation with prize rewards: History and typology of technology prizes and a new contest design for innovation in African agriculture. William A. Masters and Benoit Delbecq, 2008.

834. Local politics, political institutions, and public resource allocation. Nethra Palaniswamy and Nandini Krishnan, 2008.

833. Trade protection and tax evasion: Evidence from Kenya, Mauritius, and Nigeria. Antoine Bouet and Devesh Roy, 2008.

832. Global carbon markets: Are there opportunities for Sub-Saharan Africa? Elizabeth Bryan, Wisdom Akpalu, Mahmud Yesuf, and Claudia Ringler, 2008.

831. Anatomy of a crisis: The causes and consequences of surging food prices. Derek Heady and Shenggen Fan, 2008

830. Credit constraints, organizational choice, and returns to capital: Evidence from a rural industrial cluster in China. Jianqing Ruan and Xiaobo Zhang, 2008.

829. The future of global sugar markets: Policies, reforms, and impact. Proceedings of a public conference. Jean-Christophe Bureau, Alexandre Gohin, Loïc Guindé, Guy Millet, Antônio Salazar P. Brandão, Stephen Haley, Owen Wagner, David Orden, Ron Sandrey and Nick Vink, 2008.

828. The impact of climate change and adaptation on food production in low-income countries: Evidence from the Nile Basin, Ethiopia. Mahmud Yesuf, Salvatore Di Falco, Claudia Ringler, and Gunnar Kohlin, 2008.

827. The Philippines: Shadow WTO agricultural domestic support notifications. Caesar Cororaton, 2008.

826. What determines adult cognitive skills? Impacts of preschooling, schooling, and post-schooling experiences in Guatemala. Jere R. Behrman, John Hoddinott, John A. Maluccio, Erica Soler-Hampejsek, Emily L. Behrman, Reynaldo Martorell, Manuel Ramírez-Zea, andAryeh D. Stein, 2008.

825. Accelerating Africa's food production in response to rising food prices: Impacts and requisite actions. Xinshen Diao, Shenggen Fan, Derek Headey, Michael Johnson, Alejandro Nin Pratt, Bingxin Yu, 2008.

824. The effects of alternative free trade agreements on Peru: Evidence from a global computable general equilibrium model. Antoine Bouët, Simon Mevel, and Marcelle Thomas, 2008.

823. It's a small world after all. Defining smallholder agriculture in Ghana. Jordan Chamberlin, 2008

822. Japan: Shadow WTO agricultural domestic support notifications. Yoshihisa Godo and Daisuke Takahashi, 2008.

821. United States: Shadow WTO agricultural domestic support notifications. David Blandford and David Orden, 2008.

820. Information flow and acquisition of knowledge in water governance in the Upper East Region of Ghana. Eva Schiffer, Nancy McCarthy, Regina Birner, Douglas Waale, and Felix Asante, 2008.

819. Supply of pigeonpea genetic resources in local markets of Eastern Kenya. , Patrick Audi, and Richard Jones, 2008.

818. Persistent poverty and welfare programs in the United States. John M. Ulimwengu, 2008.

817. Social learning, selection, and HIV infection: Evidence from Malawi. Futoshi Yamauchi and Mika Ueyama, 2008.

816. Evaluating the impact of social networks in rural innovation systems: An overview. Ira Matuschke, 2008.

815. Migration and technical efficiency in cereal production: Evidence from Burkina Faso. Fleur S. Wouterse, 2008. 


\section{INTERNATIONAL FOOD POLICY RESEARCH INSTITUTE}

\section{www.ifpri.org}

IFPRI HEADQUARTERS

2033 K Street, NW

Washington, DC 20006-1002 USA

Tel.: +1-202-862-5600

Fax: +1-202-467-4439

Email: ifpri@cgiar.org

IFPRI ADDIS ABABA

P. O. Box 5689

Addis Ababa, Ethiopia

Tel.: +251 116463215

Fax: +251 116462927

Email: ifpri-addisababa@cgiar.org

IFPRI NEW DELHI

CG Block, NASC Complex, PUSA

New Delhi 110-012 India

Tel.: 9111 2584-6565

Fax: 9111 2584-8008 / 2584-6572

Email: ifpri-newdelhi@cgiar.org 